\section{Nauplius}

The Journal OF THE

Brazilian Crustacean Society

\author{
e-ISSN 2358-2936 \\ www.scielo.br/nau \\ www.crustacea.org.br
}

\title{
Growth and longevity of the spider crab Libinia ferreirae (Majoidea, Epialtidae)
}

Geslaine Rafaela Lemos Gonçalves ${ }^{1}$ (D) orcid.org/0000-0001-7443-6913

Lizandra Fernandes Miazaki ${ }^{3}$ (D) orcid.org/0000-0002-1678-3228

Eduardo Antonio Bolla Junior ${ }^{1,2}$ (D) orcid.org/0000-0002-0493-5095

Raphael Cezar Grabowski (D) orcid.org/0000-0001-9414-8310

Rogério Caetano da Costa ${ }^{3}$ (D) orcid.org/0000-0002-1342-7340

Antonio Leão Castilho ${ }^{1}$ (D) orcid.org/0000-0003-0001-9054
${ }^{1}$ Group of Studies on Crustacean Biology, Ecology and Culture (NEBECC), Zoology Department, Institute of Bioscience of Botucatu, São Paulo State University. 18618- 970, Botucatu, São Paulo, Brazil.
${ }^{2}$ Federal Institute of São Paulo, Avaré campus. 18707-150, Avaré, São Paulo Brazil.
${ }^{3}$ Laboratory of Biology and Ecology of Marine and Freshwater Shrimps (LABCAM), Biological Science Department, Faculty of Sciences of Bauru, São Paulo State University. 17033-360, Bauru, São Paulo Brazil.

ZOOBANK: http://zoobank.org/urn:lsid:zoobank.org:pub:0CE2C0A8-001A-4269B7C2-8AFD930B8121

\section{Abstract}

We estimated the growth parameters of the spider crab, Libinia ferreirae (age, asymptotic size and growth rate) using the von Bertalanffy growth equation model. We obtained nine cohorts for female carapace asymptotic width $\left(\mathrm{CW}_{\infty}\right)=64.32 \mathrm{~mm}$, growth coefficient $\left(\right.$ day $\left.^{-1}\right)(\mathrm{k})=0.0027$ e $_{0}=$ 0.77 days $)$ and seven for males $\left(\mathrm{CW}_{\infty}=81.93 \mathrm{~mm}, \mathrm{k}=0.0021\right.$ e $_{0}=0.49$ days). The longevity for males was higher than that for females, estimated 2,156 days ( 5.91 years) and 1,706 days ( 4.68 years), respectively. The growth curves for males and females differed $(\mathrm{F}=34.67 \mathrm{e} \mathrm{p}<0.001)$. Males reached gonadal maturity before morphometric maturity and occurred at 8.8 and 16.6 months of life, respectively. Females reach gonad and morphometric maturity synchronously and this was estimated to occur at about 11.42 months of life. These crabs invest a great amount of energy in growth during a brief period of their development until reaching the terminal moult. This growth strategy would bring less wear to the organism and consequently a

CORRESPONDING AUTHOR Geslaine Rafaela Lemos Gonçalves geslainelemos@yahoo.com.br

SUBMITTED 13 August 2019 ACCEPTED 8 October 2019 PUBLISHED 17 February 2020 greater longevity.

\section{KeYwords}

Growth, von Bertalanffy, puberty moult, age, symbiotic relationship 


\section{INTRODUCTION}

Due to their hard exoskeleton, crustacean growth is a discontinuous process occurring incrementally. Individuals grow with the production of a new exoskeleton, occurring at each moult (Petriella and Boschi, 1997). This growth is defined as: determinate, where some species enter terminal anecdysis and invest all their energy in reproduction (individuals grow to a certain size and no longer grow for the rest of their lives); and indeterminate growth for the majority, who continue to invest energy in moulting as well as in reproduction (growth occurs during all their life) (McLay, 2015).

In the superfamily Majoidea, all individuals undergo several moults before the pre-puberty moult for juvenile growth (that may coincide with the onset of gonadal maturity) and terminal for the ultimate moult, preceding the onset of the adult stage. The adult stage is reached after the terminal moult, which marks both gonadal maturity and morphological maturity, i.e., individuals of both sexes present functional reproductive cells and well-defined secondary sexual morphological characters (Hartnoll, 1963; 1982). However, males of some Majoidea species can reach gonadal maturity during pre-pubertal moulting (the second to last moult before terminal moulting), these crabs have gonad maturity but no morphometric maturity. This may allow opportunistic copulation before going through the last moult (terminal moult and end of growth), where individuals have maturity (gonadal and morphometric), and are able to transfer sperm and guard females (Laufer and Ahl, 1995; Gonçalves et al., 2017a). In this way, individuals who undergo early gonadal maturity have an altered reproductive role within the species population dynamics. This may lead to selection for an extended pre-puberty intermoult stage (Laufer and Ahl, 1995; Sal Moyano and Gavio, 2012). The spider crab Libinia ferreirae Brito Capello, 1871 is included in this superfamily, the females of these species reach gonadal and morphometric maturity simultaneously; unlike males, who reach gonadal maturity before morphometric maturity (Gonçalves et al., 2017a).

Because of this growth pattern, spider crabs do not exhibit continuous growth during their lifespan, i.e., when crabs reach maturity (gonadal, morphometric or functional), they do not present apparent growth, as seen in other brachyurans (Hartnoll, 1982). Whilst investigating gonad development, Gonçalves et al. (2017b) did not observe the production of a new carapace in L.ferreirae when removing the calcified carapace from adult crabs, as seen in the study of Teixeira et al. (2008) with Epialtus brasiliensis (Dana 1852). Thus, adult crab size is set by the number of pre-pubertal moults and depends on factors that may influence its life cycle, such as food availability, survival and gonadal and morphometric maturation (Hartnoll et al., 1993).

Studies concerning the growth and age of the species are essential to understanding their basic biology, including how fast they grow and how long they can live. Such information is necessary for sustainable fishery management, which aims to preserve animal populations that are accidentally exploited (Castilho et al., 2015). Crustacean age is considered one of the most important biological variables; it enables calculations of growth, mortality rates, productivity and provides valuable information about population dynamics and population size (Campana, 2001). Using equations, one can estimate the growth of an organism, defined by measurements of any structure that may vary in size over time. The von Bertalanffy (1938) equation is the most useful mathematical equation that estimates growth parameters, while also considering individual biological processes.

To date, there have been no studies that use the von Bertalanffy model to determine age for Majoidea crabs. Generally, such studies are carried out using laboratory breeding techniques (Miller and Watson, 1976; González-Gurriarán et al., 1995; Duran et al., 2013), which may include making observations on the tissues and exoskeleton (Hébert et al., 2002), measuring the proportion of radionucleotide activity of ${ }^{228} \mathrm{Th} /{ }^{228} \mathrm{Ra}$ in the exoskeleton (Le Foll et al., 1989), or analysing the condition and integrity of the carapace through the degradation of the cheliped or dactyl (Fonseca and Sainte-Marie, 2008). The lack of studies focusing on growth and age may be associated with the difficulty in fitting growth models, arising from the occurrence of a terminal moult.

The von Bertalanffy growth model is the most commonly used model in studies on crustacean growth; however, this model is normally used to describe 
the growth during the benthic phase, limiting its applicability to the complete life history of some species (Urban, 2002). Petriella and Boshi (1997) proposed that this model can be adjusted for species that have fast growth, such as Penaeoidea and Sergestoidea shrimps.

The distribution of the spider crab, L. ferreirae is restricted to the western Atlantic, from Costa Rica to Uruguay, and inhabits depths up to $35 \mathrm{~m}$ (Melo, 1996; Tavares and Santana, 2012). This species also maintains a symbiotic relationship with the jellyfish, Lychnorhiza lucerna, (Haeckel, 1880) (Scyphomedusa). During their larval and juvenile stages, the crabs grow together with the medusa and use the host for protection, transportation and as a food source. When they reach the adult stage, they live in the benthos associated with many organisms attached to their carapace such as anemones, polychaetes, algae among others (Gonçalves et al., 2017a). Thus, these crabs can move on the sea bed camouflaged (Nogueira Jr. and Haddad, 2005; Winter and Masunari, 2006). This symbiotic behavior may result in increased survival and individual longevity.

To date, studies on this spider crab L. ferreirae have addressed their larval development (Anger et al., 1989; Bakker et al., 1990), symbiotic relationships (Nogueira Jr. and Haddad, 2005; Winter and Masunari, 2006; Gonçalves et al., 2016; 2017b), morphology and maturity (Tavares and Santana, 2012; Gonçalves et al., 2017a) and distribution (Braga et al., 2007). However, little is known about the growth of this species. Based on this knowledge, this study aims to estimate the growth parameters, including age (days), asymptotic size, and growth rate for both sexes of L. ferreirae in the Cananéia region, São Paulo State, on the southeastern coast of Brazil.

\section{Material and Methods}

\section{Biological sampling}

Sampling was carried out monthly from July 2012 to May 2014 at seven pre-established sampling stations, using a shrimp-fishing boat outfitted with double-rig nets. Each trawl lasted for 30 minutes in the Estuarine-Lagoon System of Cananéia-Iguape $\left(\approx 25^{\circ} 05^{\prime} S ; \approx 47^{\circ} 53^{\prime} \mathrm{O}\right)$ and the adjacent oceanic area.

Crabswere identified according to the morphological features noted in the studies carried out by Melo (1996) and Tavares and Santana (2012). Specimens were sexed based on the shape of the abdomen (an elongated shape for males and an oval shape for females) and the number of pleopods (two pairs of pleopods for males and four pairs for females) (Ingle, 1977; Sampedro et al., 1999). Afterwards, the carapace width (CW; the greatest distance between the lateral body edges, disregarding thorns and/or tubercles) was measured using a digital calliper (to the nearest $0.01 \mathrm{~mm}$ ) and a stereomicroscope (Zeiss' Stemi SV6) outfitted with an image capturing system (Zeiss Stemi 2000-C). To analyse animal size data, $95 \%$ confidence intervals were obtained using the bootstrap interaction method ( $\mathrm{R}$ studio version 1.0.153).

\section{Individual growth}

We analysed the growth parameters for L. ferreirae based on the similarity of the estimated parameters found in Gonçalves et al. (2017a; 2017b), to the size and maturity of crabs in real ecosystems. Specimens with CW smaller than $4 \mathrm{~mm}$ were sexually undifferentiated and were not included in the size class distribution. Growth analyses were performed based on the von Bertalanffy (1938) growth model, following the methodology adopted by Fonseca and D'Incao (2003). The modal values were determined in each CW frequency distribution (size classes of $2 \mathrm{~mm}$ ) using the program PeakFit (Automatic Peak Fitting Detection and Fitting, Method I-Residual, no Data Smoothing). The obtained numerical peak values were plotted in a scatter plot (time versus age), from which we analysed the cohorts' growth rhythm according to each growth model, namely:

von Bertalanffy (1938) model: $\mathrm{CW}_{\mathrm{t}}=\mathrm{CW}_{\infty}$ $\left.\left[1-\mathrm{e}^{-\mathrm{k}(\mathrm{t}-\mathrm{t} 0}\right)\right]$; where, for this model: $\mathrm{CW}_{\mathrm{t}}=$ individual's carapace width at age $t ; C W_{\infty}=$ carapace asymptotic width; $k=$ growth coefficient $\left(\right.$ day $\left.^{-1}\right) ; \mathrm{t}_{0}=$ theoretical age at size zero.

The growth parameters $\mathrm{CW}_{\infty}, \mathrm{k}$ and $\mathrm{t}_{0}$ were estimated using the Solver tool, available in Microsoft $\operatorname{Excel}^{\circledR}$ (in the Microsoft Office ${ }^{\circledast}$ software pack), minimizing the sum of the squared residuals. The obtained modal progression was evaluated based on the similarity observed between the estimated parameters and the sampled biological data, considering its biological coherence. We selected growth curves with estimated 
asymptotic length values that were similar to the average CW recorded for post-pubertal adults of both sexes (for more details, see Gonçalves et al., 2017a). Next, we standardized the onset of each curve so that it began at age 0 (von Bertalanffy model). Using the software TableCurve $^{\circledR} 2 \mathrm{~d}$ v.5.01 $\left(\right.$ Systat $^{\circledR}$ ), we obtained an average growth curve for each sex, with a $95 \%$ confidence interval for mean and prediction interval for each curve. Statistically significant differences between male and female growth curves were tested using an F-test at the $\mathrm{p}=0.05$ level significance (Cerrato, 1990).

\section{Age and longevity}

Longevity was estimated by inverse von Bertalanffy (1938) equation, with modifications suggested by D'Incao and Fonseca (1999), $t_{0}=0$ and CW $/ \mathrm{CW} \infty=$ 0.99 , while the longevity equation was $\mathrm{t}=\left(t_{0}-(1 / \mathrm{k})\right.$ Ln $\left.\left(1-\mathrm{CW}_{\mathrm{t}} / \mathrm{CW}_{\infty}\right)\right)$ (Miaziki et al., 2019).

The age in months when $50 \%$ of the males and females of L.ferreirae became sexually mature (gonadal and morphometrically) was calculated using the inverse of the growth equation $\left(\mathrm{t}=\left(t_{0}-(1 / \mathrm{k}) \operatorname{Ln}\left(1-\mathrm{CW}_{\mathrm{t}} /\right.\right.\right.$ $\left.\mathrm{CW}_{\infty}\right)$ ) (King, 1995), based on the maturity sizes determined by Gonçalves et al. (2017a): for males, 35 and $53 \mathrm{~mm} \mathrm{CW}$ for gonad and morphometric maturity respectively, while for females, $38 \mathrm{~mm} \mathrm{CW}$ for both maturities. Males of this superfamily Majoidea become gonadally mature before terminal moult, unlike females that reach gonadal maturity and morphometric maturity at the terminal moult (Sampedro et al., 1999; Sal Moyano and Gavio, 2012; Gonçalves et al., 2017a).

\section{RESULTS}

\section{Growth and longevity}

A total of 611 L. ferreirae were analyzed (CW ranging from 4.4 to $77.84 \mathrm{~mm}$ ). Among them, we identified 110 immature females (mean $24.57 \pm 11.01 \mathrm{~mm} \mathrm{CW}$ ) and 264 mature females $(49.09 \pm 5.32 \mathrm{~mm} \mathrm{CW})$. For males, we found $93(23.48 \pm 11.71 \mathrm{~mm} \mathrm{CW})$ immature individuals and identified $144(50.20 \pm 10.13 \mathrm{~mm}$ $\mathrm{CW}$ ) mature (gonadal and morphometric) individuals. The largest individuals captured measuring 71.64 and $77.84 \mathrm{~mm}$ CW for females and males, respectively. Our sample size was limited by low crab abundance, however, we used ecological parameters established by Gonçalves et al. (2017a; 2017b), and the data was tested for their confidence limits. We have $95 \%$ confidence (bootstrap interactions: 100000) that the mean CW for female is somewhere between $-0.37 \mathrm{~mm}$ lower than for males up to $4.72 \mathrm{~mm}$ higher than for females.

We identified nine cohorts for females (Fig. 1) and seven for males (Fig. 2). In most of the months sampled, occurrence of juvenile crabs was common for both sexes. In Sept/Oct 2012 the recruitment increased for both sexes (Fig. 1 and 2). For females, the accentuated peak of abundance occurred during the spring/summer 2012 and summer in Jan/2013 and 2014 (Fig. 1). Males were absent only in Mar/13 and $\mathrm{Feb} / 14$, and present in the remaining months with greatest abundance in similar periods to females (Fig. 2).

Estimated parameters, based on the average growth curves, resulted in $\mathrm{CW}_{\infty}=64.32 \mathrm{~mm}, k=0.0027$ and $t_{0}=0.77$ days for females and $\mathrm{CW}_{\infty}=81.93 \mathrm{~mm}, k=$ 0.0021 and $t_{0}=0.49$ days for males (Fig. 3 ). Estimated age for female was 1.706 days (4.68 years), whereas, males it was 2.156 days ( 5.91 years).

The growth curves obtained for females and males using the von Bertalanffy (1938) model were significantly different $\left(F_{\text {critic }}=2.71, F_{\text {calculated }}=34,67 ; d f=\right.$ $87 ; P<0.001)$, supporting the notion that a single curve cannot be applied to explain the growth of both sexes.

Time taken, in days, to reach gonadal maturity was estimated approximately at 342.7 (11.42 months) and 264.6 ( 8.8 months) for females and males, respectively. Time taken, in days, for males to reach morphometric maturity was 500.33 days (16.6 months). This parameter was not estimated for females, since gonadal and morphometric maturity occur concomitantly. 


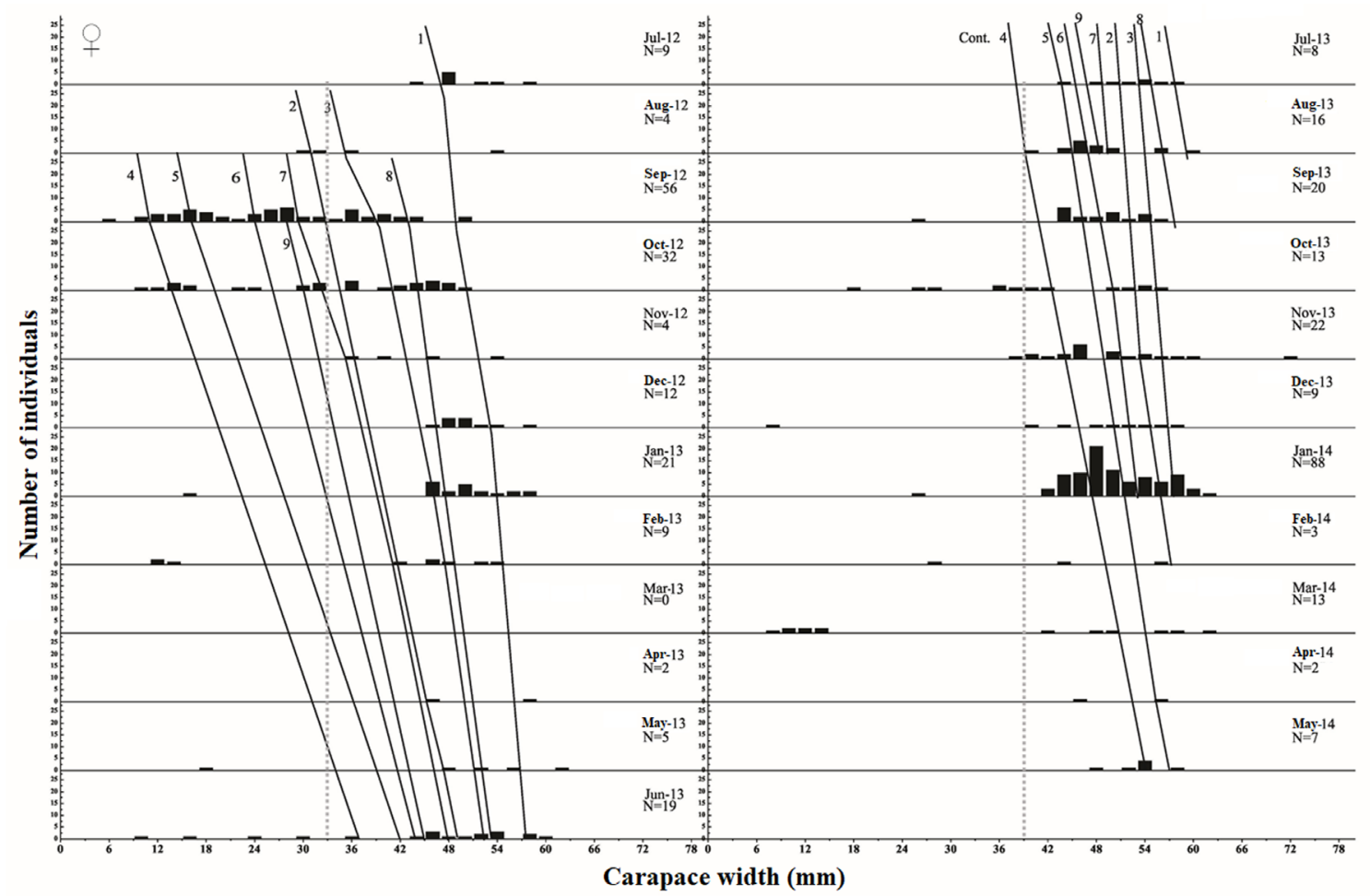

Figure 1. Libinia ferreirae Brito Capello, 1871. Carapace width (CW) frequency histograms of females in the Cananéia region from June 2002 and May 2004. Lines represent the cohorts followed during the studied period to describe the individual growth. Dashed greys lines represent the size that crab reaches the gonadal/morphometric maturity, around $39 \mathrm{~mm} \mathrm{CW}$, according to Gonçalves et al. (2017a).

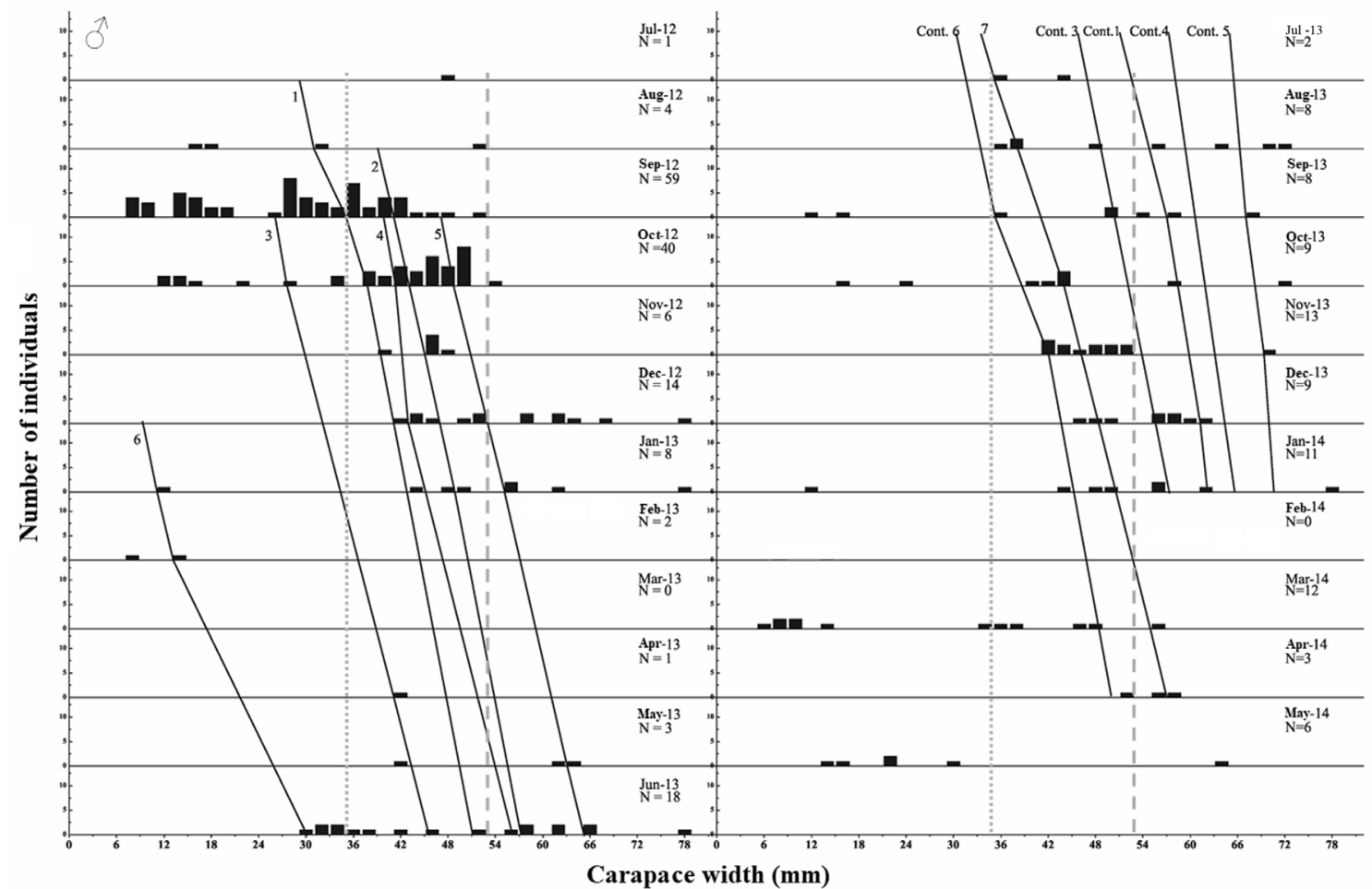

Figure 2. Libinia ferreirae Brito Capello, 1871. Carapace width (CW) frequency histograms of males in the Cananéia region from June 2002 and May 2004. Lines represent the cohorts followed during the studied period to describe the individual growth. Dashed greys lines represent the sizes that crabs reach the gonadal maturity, around $35 \mathrm{~mm} \mathrm{CW}$ and morphometric maturity, around $53 \mathrm{~mm}$ CW, respectively, according to Gonçalves et al. (2017a). 


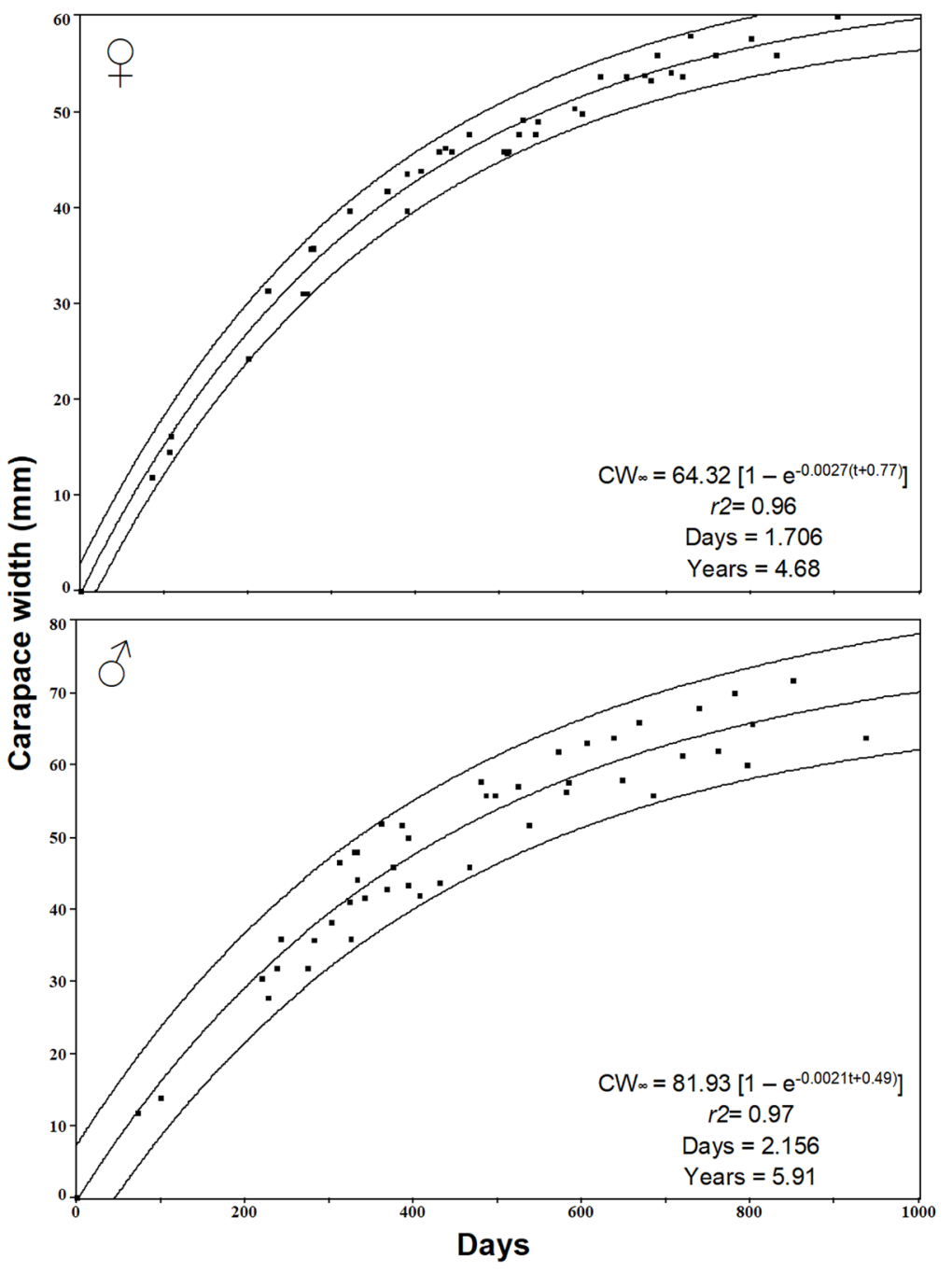

Figure 3. Libinia ferreirae Brito Capello, 1871. Estimated growth curves for both males and females when applying the von Bertalanffy (1938) growth model. Samples were taken in the Cananéia region, São Paulo State, from July 2012 through May 2014. Central line= average growth curve; inner line= confidence interval $(95 \%)$; external line= prediction interval $(95 \%)$.

\section{Discussion}

The equation of the von Bertalanffy (1938) growth model may have its limitations when applied to Majoidea crabs, such as the crab L. ferreirae, because they have determinate growth. However, with the use of well-established parameters, adjustments can be made to provide accurate results. It is essential to understand the biology and ecology of the species, especially concerning its period of gonadal and morphometric maturity, since the Majoidea crabs reach their maturity before ceasing growth (during the terminal moulting). This study was based on previous knowledge of reproductive maturity and ecology of Majoidea studied by Gonçalves et al. (2017a; 2017b), in the same region. It is important to use a representative sampling technique that shows the size distribution of crabs in the population, in order to accurately calculate carapace asymptotic width $(\mathrm{CW} \infty)$. When considering the best growth coefficient $(\mathrm{k})$, a broad literature search is required, especially considering closely related species or organisms in a similar environment. Garcia and Le Reste (1981) reinforce that it is difficult to determine precisely the growth of an individual from birth to death because of changes in their metabolism rates and in the environment in which they live.

In this study, we observed the occurrence of individuals of varying age and size allowing us to determine growth and longevity for both sexes. The highest peaks of juvenile abundance occurred in Sept 
and Oct / 2012 for both sexes, and Jan / 2014 for females, showing that these crabs prefer spring and summer to breed. Increased temperature conditions accelerate growth; furthermore, these periods support greater food availability (phytoplankton and zooplankton). Thus, warmer temperatures are favorable for the survival of larval and juvenile phases. However, L. ferreirae demonstrates continuous reproduction with reproductive peaks in certain seasons as seen in Gonçalves et al. (2017b).

Juvenile $L$. ferreirae use symbiotic relationships as a camouflage strategy; this allows them to avoid predation and consequentially the loss of appendages or even death. When using jellyfishes while in the juvenile stage, these crabs are less vulnerable in the environment and cease to be part of the food web for countless other animals. Furthermore, as adults, they act as hosts to a wide range of epibiont organisms on their carapace, allowing them to live unnoticed in the environment through the use of this natural camouflage (Nogueira Jr. and Haddad, 2005; Hultgren and Stachowicz, 2011; Gonçalves et al., 2017b).

Larger males are likely to have increased mating success and may also provide a protective function during or after copulation (Hartnoll, 1969; 1982). Additionally, O’Brien et al. (1999), when studying Libinia dubia H. Milne Edwards, 1834, observed that males were larger than females, while for Libinia emarginata Leach, 1815, De Goursey and Auster (1992) observed that males seemed to possess body sizes approximately $15 \%$ larger than those observed for females. However, males allocate more energy toward growth and toward developing secondary sexual characteristics (Hartnoll, 1982), tending to take a longer time to reach their morphometric maturity in comparison to females, as shown by Teixeira et al. (2008), with Majoidea crab E. brasiliensis. This holds true for L.ferreirae because they develop well-defined secondary sexual characteristics, such as large chelipeds (Gonçalves et al., 2017a), and take longer to reach the terminal moult.

Large size may be beneficial in females, if they are able to accommodate a higher number of fertilized eggs on the ventral portion of their abdomen during reproduction (Hartnoll, 1969; 1982; Conan and Comeau, 1986). Females reach their gonadal/ morphometric maturity in the terminal moult; however, their ovarian maturation demands a large amount of energy; therefore, they divide their energy between growth and gonad maturation at the end of the juvenile instar (the penultimate instar before to the pubertal moult). Thus, the posterior moult increment may be strongly compromised (Hartnoll and Bryant, 2001) given that they preferably invest their energy in oogenesis and in embryo-related care (Varisco and Vinuesa, 2011).

The different growth and age rate observed for both sexes are strongly influenced by their reproductive traits. Females, for instance, cease their growth when they reach the terminal moult (consequently their morphometric maturity) around 1 year, instead investing their energy in production, breeding and care of fertilized eggs. On the other hand, males may remain in the pre-puberty intermoult stage for a longer period, acting as adolescent males (i.e., possessing mature gonads without mature morphometric features). As observed in this study, males reach gonad maturity before the females, by around 6 months. Many studies have shown that males are able to copulate in prepuberty (adolescent males) and may thus stay in the prepuberty intermoult for a long time before attaining the terminal moult; while copulating, they are as successful as they would be if they were morphometrically immature (Elner and Beninger, 1995; Laufer and Ahl, 1995; Sal Moyano and Gavio, 2012; Gonçalves et al., 2017a). This behavior may explain why they take a longer time to reach morphometric maturity (terminal moult), around 5 months after the females. This is supported by our results whereby males were found to be older before reaching maturity.

Fonseca and Sainte-Marie (2008) estimated the longevity for males of the snow crab Chionoecetes opilio (O. Fabricius, 1788), found in cold regions, using the capture-recapture method. The authors analyzed the wear of the cheliped and dactyl, carapace conditions and natural changes that occurred along the specimens' body; they estimated a species longevity of 7.7 years after the terminal moult. On the other hand, using radio-isotopic techniques to study this same species, Saint-Marie et al. (1995) estimated the male longevity at 6 years after the terminal moult, while females would live 4-5 years after the terminal moult. However, Fonseca and Sainte-Marie (2008) justified their higher longevity based on the sampled area, given that it is 
maintained as an ecological preservation area. Also using radio-isotopic techniques, Le Foll (1993) divided the longevity of Maja squinado (Herbst, 1788) into two stages since they present a terminal moult (representing the end of the juvenile growth period, which may last for 2-3 years) and a reproductive stage (after their terminal moult), which may last for 5-6 years.

According to our results, females of $L$. ferreirae reach the puberty moult in approximately 12 months, which is almost the same amount of time proposed for $L$. spinosa to reach maturity, according to Sal Moyano et al. (2011). For males, we determined that the puberty moult occurs at approximately 16 months, highlighting that when they reach the pre-puberty moult, males are already gonadally mature (Gonçalves et al., 2017a). Hébert et al. (2002), studying males of C. opilio, determined that they have 11 life stages prior to their terminal moult. In this case, pre-puberty would occur in 5-6-year-old individuals, and such adolescent males could take up to 5 years to reach the adult stage. However, males reach gonadal maturity prior (in smaller sizes) to females, which provides them with a higher probability of experiencing opportunistic copulations (Laufer and Ahl, 1995; Sampdro et al., 1999). Hartnoll and Bryant (2001) state that the intermoult period increases with higher individual size.

The longevity found in this study for L. ferreirae males and females was higher than the longevity found with the same estimation methods for Callinectes sapidus Rathbun, 1896 (3.02 to 3.27 years for males and 3.16 to 3.24 years for females) by Ferreira and D'Incao (2008). This crab experiences reproduction and growth constantly, bringing a high metabolic expense to the individual which naturally shortens its life span. On the other hand, L. ferreirae has determined growth, investing energy to grow for a brief period, stops growing in the terminal moult, before allocating energy after this period for reproduction. Le Foll (1993), in a study of the M. squinado crab based on radio-isotope techniques, divided the longevity of these individuals into two phases: young growth phase, which lasts 2-3 years, and a reproduction phase (after the change of puberty/terminal moult), which can last 5-6 years. These studies corroborate our results since males live longer than females and also because the longest life period occurs after the terminal moult. However, the different techniques used to estimate the growth and longevity of crustaceans may generate different results, especially when considering population genetics and their environment (Hébert et al., 2002).

Libinia ferreirae completes its life cycle in the adjacent coastal area to the city of Cananéia, SP. However, this region faces an excessive shrimp-fishing effort, in which L. ferreirae is captured as bycatch in all of their developmental stages. When this happens, individuals generally die before being discarded back to the sea, where they are exposed to the same fishing pressure as the target species. The impact of fishing on these crabs can result in population imbalances, since these species take about a year or more to reach reproductive maturity. Thus, numerous crabs are caught in the juvenile phase without having the opportunity to have reproduced. In this way, it is likely that the low abundance of this species in the region, when compared to other Brachyura crabs that reproduce at a younger age, results from the pressure of indirect fishing and bycatch of species that L. ferreirae may depend upon in the ecosystem. These fishing practices may lead to population disorders, even for animals with an evolutionary history composed of ecological relationships, as seen for $L$. ferreirae. Future studies on this population should consider a large temporal period and are necessary to verify whether the population has been undergoing any type of plasticity due to the influence of fishing activities (Ghalambor et al., 2007).

\section{ACKNOWLEDGEMENTS}

We thank for Dr. Maria Lucia Negreiros-Fransozo for useful suggestions and comments on early drafts of the manuscript; Richard Little (Language and Academic Support Services, and Charlie Savill, (MSc in Evolutionary and Behavioural Ecology) at the University of Exeter in Cornwall - UK, for assistance with English, and the "Instituto Brasileiro do Meio Ambiente e dos Recursos Naturais Renováveis" (IBAMA) for granting permission to collect the crabs. To the funding agencies: "Fundação de Amparo à Pesquisa do Estado de São Paulo” (FAPESP) (Biota/FAPESP \#2010/50188-8 and Scholarship 2014/13770-1, 2018/01659-0, 2019/00105-3), "Centro de Apoio Profissionalizante Educacional e Social” (CAPES CIMAR) (No. 23038.004310/201485 ), and to "Conselho Nacional de Desenvolvimento 
Científico e Tecnológico” (CNPq) (Financial Support \# 406006/2012-1, Research Scholarships PQ 303371/2011-0 and 311034/2018-7), for providing financial support during field collections and visiting activities.

\section{RefERenCES}

Anger, K.; Harms, J.; Montú, M. and Bakker, C. 1989. Growth and respiration during the larval development of a tropical spider crab, Libinia ferreira (Decapoda: Majidae). Marine Ecology Progress Series, 54: 43-50.

Bakker, C.; Montu, M.; Anger, K. and Harms, J. 1990. Larval development of a tropical spider crab, Libinia ferreirae Brito Capello, 1871 (Decapoda: Majidae), reared in the laboratory. Meeresforschung, 33: 90-103.

Braga, A.A.; Fransozo, A.; Bertini, G. and Fumis, P.B. 2007. Bathymetric distribution and recruitment of the spider crab Libinia spinosa $\mathrm{H}$. Milne Edwards 1834 in the Ubatuba and Caraguatatuba regions, northern coast of São Paulo, Brazil (Crustacea, Brachyura, Majoidea, Pisidae). Senckenbergiana Biologica, 87: 7-16.

Campana, S.E. 2001. Accuracy, precision and quality control in age determination, including a review of the use and abuse of age validation methods. Journal of Fish Biology, 59: 197-242.

Castilho, A.L.; Bauer, R.T.; Freire, F.A.M.; Fransozo, V.; Costa, R.C.; Grabowski, R.C. and Fransozo, A. 2015. Lifespan and reproductive dynamics of the commercially important sea bob shrimp Xiphopenaeus kroyeri (Penaeoidea): synthesis of a 5-year study. Journal of Crustacean Biology, 35: 30-40.

Cerrato, R.M. 1990. Interpretable statistical tests for growth comparisons using parameters in the von Bertalanffy equation. Canadian Journal of Fisheries and Aquatic Sciences, 47: 14161426.

Conan, G.Y. and Comeau, M. 1986. Functional maturity and terminal moult of male snow crab, Chionoecetes opilio. Canadian Journal of Fisheries and Aquatic Sciences. 43, 1710-1719.

D'Incao, F. and Fonseca, D.B. 1999. Performance of the von Bertalanffy growth curve in penaeid shrimp: a critical approach. p. 733-737. In: J.C. von Kaupel Klein and F.R. Schram (ed), The Biodiversity Crisis and Crustacean. Proceedings of the Fourth International Crustacean Congress, Amsterdam, Netherlands, 20-24 July 1998, vol. 2. Crustacean Issues, 12. Rotterdam, A.A. Balkema.

De Goursey, R.E. and Auster, P.J. 1992. A mating aggregation of the spider crab (Libinia emarginata). Journal of Northwest Atlantic Fishery Science, 13: 77-82.

Duran, J.; Palmer, M. and Pastor, E. 2013. Growing reared spider crabs (Maja squinado) to sexual maturity: The first empirical data and a predictive growth model. Aquaculture, 409: 78-87.

Elner, R.W. and Beninger, P.G. 1995. Multiple reproductive strategies in snow crab, Chionoecetes opilio: physiological pathways and behavioral plasticity. Journal of Experimental Marine Biology and Ecology, 193: 93-112.

Ferreira, L.S. and F. D'Incao. 2008. Crescimento de Callinectes sapidus (Crustacea, Decapoda, Portunidae) no estuário da laguna dos Patos, Rio Grande do Sul, Brasil. Iheringia, Série Zoologia, 98: 70-77.

Fonseca, D.B.; Sainte-Marie, B. and Hazel, F. 2008. Longevity and change in shell condition of adult male snow crab Chionoecetes opilio inferred from dactyl wear and mark-recapture data. Transactions of the American Fisheries Society, 137: 1029-1043.

Fonseca, D.B. and D'Incao, F. 2003. Growth and reproductive parameters of Kalliapseudes schubartii in the estuarine region of the Lagoa dos Patos (southern Brazil). Journal of the Marine Biological Association of the United Kingdom, 83: 931-935.

Garcia, S. and Le Reste, L. 1981. Life cycles, dynamics, exploitation and management of coastal penaeid shrimp stocks. FAO Fisheries and Aquaculture Technical Papers, 203: 1-215.

Ghalambor, C.K.; McKay, J.K.; Carroll, S.P. and Reznick, D.N. 2007. Adaptive versus non-adaptive phenotypic plasticity and the potential for contemporary adaptation in new environments. Functional Ecology, 21: 394-407.

Gonçalves, G.R.L.; Wolf, M.R.; Costa, R.C. and Castilho, A.L. 2016. Decapod crustacean associations with scyphozoan jellyfish (Rhizostomeae: Pelagiidae) in the Southeastern Brazilian coast. Symbiosis 3: 93-198.

Gonçalves, G.R.L.; Bolla Jr, E.A.; Negreiros-Fransozo, M.L. and Castilho, A.L. 2017a. Morphometric and gonadal maturity of the spider crab Libinia ferreirae Brito Capello, 1871 (Decapoda: Majoidea: Epialtidae) at Southeastern Brazilian coast. Journal of the Marine Biological Association of the United Kingdom, 97: 289-295.

Gonçalves, G.R.L.; Grabowski, R.C.; Bochini, G.L.; Costa, R.C. and Castilho, A.L. 2017b. Ecology of the spider crab Libinia ferreirae (Brachyura: Majoidea): ontogenetic shifts in habitat use. Hydrobiologia, 795: 313-325.

Gonzalez-Gurriaran, E.; Freire, J.; Parapar, J.; Sampedro, M.P. and Urcera, M. 1995. Growth at molt and molting seasonality of the spider crab, Maja squinado (Herbst) (Decapoda: Majidae) in experimental conditions: implications for juvenile life history. Journal of Experimental Marine Biology and Ecology, 189: 183-203.

Hartnoll, R.G. 1963. The biology of Manx spider crabs. Proceedings of the Zoological Society of London, 141: 423-496.

Hartnoll, R.G. 1969. Mating in the Brachyura. Crustaceana, 16: 161-181.

Hartnoll, R.G. 1982. Growth. p. 111-196. In: D.E. Bliss (ed), The Biology of Crustacea: Embryology, Morphology and Genetics. New York, Academic Press.

Hartnoll, R.G. and Bryant, A.D. 2001. Growth to maturity of juveniles of the spider crabs Hyas coarctatus Leach and Inachus dorsettensis (Pennant) (Brachyura: Majidae). Journal of Experimental Marine Biology and Ecology, 263: 143-158.

Hartnoll, R.G.; Bryant, A.D. and Gould, P. 1993. Size distribution in spider crab populations spatial and temporal variation. Journal of Crustacean Biology, 13: 647-655.

Hébert, M.; Benhalima, K.; Miron, G. and Moriyasu, M. 2002. Molting and growth of male snowcrab, Chionoecetes opilio (O. Fabricius, 1788) (Crustacea: Majidae) in the southern Gulf of St. Lawrence. Crustaceana, 75: 671-702.

Hultgren, K. and Stachowicz, J. 2011. Camouflage in decorator crabs. p. 214-238. In: M. Stevens and S. Merilaita (eds), Animal Camouflage: Mechanisms and Function. Cambridge, Cambridge University Press. 
Ingle, R.W. 1977. The larval and post-larval development of the scorpion spider crab, Inachus dorsettensis (Pennant) (family: Majidae), reared in the laboratory. Bulletin of the British Museum (Natural History), Zoology, 30: 329-348.

Laufer, H. and Ahl, J.S.B. 1995. Mating behaviour and methyl farnesoate levels in male morphotypes of the spider crab Libinia emarginata (Leach). Journal of Experimental Marine Biology and Ecology, 193: 15-20.

Le Foll, D. 1993. Biologie et exploitation de l'araignée de mer Maja squinado (Herbst) en manche ouest. Université de Bretagne Occidentale, Brest, Ph.D. thesis. 517p. [Unpublished].

Le Foll, D.; Brichet, E.; Reyss, J.L.; Lalou, C. and Latrouite, D. 1989. Age determination of the Spider crab Maja squinado and the European lobster Homarus gammarus by ${ }^{228} \mathrm{Th} /{ }^{228} \mathrm{Ra}$ chronology: possible extension to others crustaceans. Canadian Journal of Fisheries and Aquatic Sciences, 46: 720-724.

McLay, C.L. 2015. Moulting and growth in Brachyura. p. 245-316. In: P. Castro; P.J.F. Davie; D. Guinot; F.R. Schram. and J.C. von Vaupel Klein (eds), The Crustacea, treatise on Zoology - Anatomy, Taxonomy, Biology, Volume 9. Leiden, Brill.

Melo, G.A.S. 1996. Manual de Identificação dos Brachyura (Caranguejos e Siris) do Litoral Brasileiro. São Paulo, Ed. Plêiade. 604p.

Miazaki, L.F.; Simões, S. M.; Castilho, A. L. and Costa, R.C. 2019. Population dynamics of the crab Hepatus pudibundus (Herbst, 1785) (Decapoda, Aethridae) on the southern coast of São Paulo state, Brazil. Journal of the Marine Biological Association of the United Kingdom, 99: 867-878.

Miller, R.J. and Watson, J. 1976. Growth per molt and limb regeneration in the spider crab, Chionoecetes opilio. Journal of the Fisheries Research Board of Canada, 33: 1644-1649.

Nogueira Jr, M. and Haddad, M.A. 2005. Lychnorhiza lucerna (Scyphozoa, Rhizostomeae) and Libinia ferreirae Brito Capello (Brachyura, Majidae) association in southern Brazil. Revista brasileira de Zoologia, 22: 908-912.

O’Brien, S.B.; Landau, M. and Able, K.W. 1999. Sex ratios of two species of spider crabs, Libinia dubia H. Milne Edwards, 1834 and L. emarginata Leach, 1815: in the area of Great Bay, New Jersey. Crustaceana, 72, 187-192.
Petriella, A.M. and Boschi, E.E. 1997. Crecimiento en crustáceos decápodos: Resultados de investigaciones realizadas en Argentina. Investigaciones Marinas, 25: 135-157.

Sainte-Marie, B.; Raymond, S. and Brêthes, J.C. 1995. Growth and maturation of the benthic stages of male snow crab, Chionoecetes opilio (Brachyura: Majidae). Canadian Journal of Fisheries and Aquatic Sciences, 52: 903-924.

Sal Moyano, M. and Gavio, M.A. 2012. Comparison of mating behavior and copulation in male morphotypes of the spider crab Libinia spinosa (Brachyura: Majoidea: Epialtidae). Journal of Crustacean Biology, 32: 31-38.

Sal Moyano, M.P.; Gavio, M.A. and Maggi, M.D. 2011. Morphometric and gonad maturity of the spider crab Libinia spinosa (Crustacea: Brachyura: Majoidea: Epialtidae) in Argentina. Journal of the Marine Biological Association of the United Kingdom, 91: 837-844.

Sampedro, M.P.; González-Gurriarán, E.; Freire, J. and Muíño, R. 1999. Morphometry and sexual maturity in the spider crab Maja squinado (Decapoda: Majidae) in Galicia, Spain, Journal of Crustacean Biology, 19: 578-592.

Tavares, M. and Santana, W. 2012. On the morphological differentiation between Libinia spinosa and L. ferreirae (Crustacea: Brachyura: Majoidea: Epialtidae). Zoologia, 29: 577-588.

Teixeira, G.M.; Fransozo, V.; Castilho, A.L.; da Costa, R.C. and de Morais Freire, F.A. 2008. Size distribution and sex ratio in the spider crab Epialtus brasiliensis (Dana 1852) associated with seaweed on a rocky shore in southeastern Brazil (Crustacea, Decapoda, Brachyura, Majoidea, Epialtidae). Senckenbergiana biologica, 169-175.

Urban, H.J. 2002. Modeling growth of different developmental stages in bivalves. Marine Ecology Progress Series, 238: 109-114.

Varisco, M. and Vinuesa, J. 2011. Reproductive biology of the spider crab Leucippa pentagona (Decapoda: Epialtidae), in Bustamante Bay, Argentina. Latin American Journal of Aquatic Research, 39: 471-480.

von Bertalanffy, L. 1938. A quantitative theory of organic growth. Human Biology, 10: 181-213.

Winter, V.C. and Masunari, S. 2006. Macroepizoismo em Libinia ferreirae (Crustacea, Brachyura, Majidae). Iheringia, Série Zoologia, 96: 135-140. 